\title{
BENGKEL KERJA KOMUNIKASI : Upaya Pemberdayaan Mahasiswa Perspektif Manajemen Sumber Daya Manusia
}

\author{
Farida Nurul R \\ Surokim \\ Netty Dyah K \\ Nikmah Surayandari \\ Program Studi Ilmu Komunikasi, Universitas Trunojoyo Madura \\ Email :wawafarida@gmail.com
}

\begin{abstract}
ABSTRAK
Sumber daya manusia adalah salah satu komponen terpenting yang ada di dalam suatu perusahaan. Peranan sumber daya manusia di era perkembangan teknologi tampak berperan sekali. Walaupun teknologi secanggih apapun tidak dapat berjalan jika tidak diproses oleh manusia. Tulisan ini mencoba membahas mengenai model Bengkel Kerja Komunikasi dari sisi manajemen sumber daya manusia. Mahasiswa merupakan sumber daya manusia potensial dalam Bengkel Kerja Komunikasi ini. Istilah SDM mengandung konotasi yang bersangkutan dengan kondisi manusia pada umumnya, baik di dalam maupun di luar organisasi. Sasaran yang ingin dicapai oleh manajemen SDM adalah untuk meningkatkan konstribusi dari orang yang ada dalam organisasi.
\end{abstract}

Key Word : manajemen sumber daya manusia, laboratorium, Transferable Skill, Bengkel Kerja Komunikasi

\section{PENDAHULUAN}

Menurut Undang-Undang Republik Indonesia nomor 20 tahun 2003 tentang sistem pendidikan nasional, pendidikan adalah usaha sadar dan terencana untuk mewujudkan suasana belajar dan proses pembelajaran agar peserta didik secara aktif mengembangkan potensi dirinya untuk memiliki kekuatan spiritual keagamaan, pengendalian diri, kepribadian, kecerdasan, akhlak mulia, serta keterampilan yang diperlukan dirinya, masyarakat, bangsa dan negara.

Tujuan Pendidikan Nasional adalah untuk mengembangkan potensi peserta didik agar menjadi manusia yang beriman dan ber- takwa kepada Tuhan Yang Maha Esa, berakhlak mulia, sehat, berilmu, cakap, kreatif, mandiri, dan menjadi warga negara yang demokratis serta bertanggung jawab. Untuk mewujudkan tujuan mulia tersebut, sekolah sebagai lembaga penyelenggara pendidikan pun memiliki peranan yang sangat besar untuk keberhasilan suatu pendidikan. Mulai dari peran guru, lingkungan belajar sampai pada ketersediaan fasilitas belajar mengajar. Salah satu fasilitas dalam proses belajar mengajar yang tidak boleh dikesampingkan adalah Laboratorium. Diharapkan laboratorium yang tersedia merupakan tempat latihan yang memiliki kesamaan operasional dan peralatan 
dengan yang akan digunakan didalam tempat kerjanya kelak. Laboratorium merupakan perangkat kelengkapan akademik dalam menunjang kegiatan proses belajar mengajar. Selain itu, laboratorium juga merupakan tempat melakukan aktifitas praktikum untuk mengaplikasikan teori ke dalam praktek.

Menurut Konsorsium Ilmu Pendidikan (Moh. Amien, 1988:1), laboratorium diartikan sebagai sarana, prasarana dan mekanisme kerja yang menunjang secara unik satu atau lebih dharma perguruan tinggi melalui pengalaman langsung dalam membentuk keterampilan, pemahaman, dan wawasan dalam pendidikan dan pengajaran serta dalam pengembangan ilmu dan teknologi dan pengabdian pada masyarakat. Sedangkan menurut PP No.25/ 1980, pasal 27, laboratorium/studio adalah sarana penunjang jurusan dalam satu atau seni tertentu sesuai dengan keperluan bidang studi yang bersangkutan.

Sebagai universitas baru, UTM masih banyak mempunyai kekurangan baik dari SDM praktek maupun infrastruktur penunjang pendidikan. Sebagai prodi yang sebagian besar keilmuannya membutuhkan skill langsung, maka keberadaan laboratorium komunikasi menjadi sangat penting sebagai sarana praktek langsung dalam mempersiapkan skill yang kompetitif namun transferable skill belum dapat secara optimal bisa diterapkan di prodi ini. Dengan berbagai kekurangan baik infrastrukturmaupunmetodepembelajarannya, laboratorium prodi komunikasi UTM saat ini masih sebatas tempat pasif pembantu prasarana mata kuliah. Padahal sebenarnya keberadaan laboratorium dalam prodi komunikasi menjadi sangat penting bukan hanya sebagai prasarana pendamping mata kuliah praktek, namun dapat menjadi sarana bengkel kerja komunikasi sebagi upaya meminimalisasi pengangguran intelektual.
Keberadaan laboratorium komunikasi sebagai wahana bengkel kerja komunikasi untuk mempersiapakan mahasiswa siap terjun di dunia kerja yang kompetitif, inovatif dan kreatif bukan sesuatu yang tidak mungkin terjadi. Prodi Ilmu Komunikasi UPN Surabaya dan Stikom Surabaya merupakan salah satu contoh prodi yang memiliki laboratorium komunikaksi yang sangat mapan. Di laboratorium inilah prodi komunkasi UPN dan Stikom mencetak lulusannya yang mempunyai skill kompetitif, inovatif dan kreatif sehingga siap menjadi lulusan yang tidak hanya siap mencari kerja, namun siap menciptakan peluang kerja bagi masyarakat sekitar.

Demi kelancaran dan kenyamanan dalam penggunaan dan pemanfaatan laboratorium, maka perlu adanya pengelolaan dan penataan yang baik secara berkala yang dilakukan oleh penanggung jawab laboratorium. Hal inilah yang akan diuraikan dalam makalah ini dengan menggunakan perspektif manajemen sumber daya manusia. Mahasiswa sebagai sumber daya manusia yang secara kultural mengelola laboratorium ini dipandang sebagai sosok potensial dalam pengembangan dan fungsi laboratorium ini di masa depan.

\section{TINJAUAN PUSTAKA}

\section{Transferable Skill}

Transferable skills adalah ketrampilan yang dapat ditransfer di tempat kerja untuk menyelesaikan pekerjaan. Dari semua ketrampilan yang dimiliki oleh seseorang transferable skills merupakan ketrampilan utama yang dibutuhkan untuk memasuki dunia kerja sebab transferable skills ini merupakan portable skills yang dimiliki seseorang dan siap dimanfaatkan untuk menyelesaikan pekerjaan di tempat kerja (Copland 2006; Smith, 2003; QAA, 2000). 
Sejak beberapa tahun yang lalu transferable skills dikembangkan University of Westminster (2004) dan University of Cambridge (2004). Prinsip dasar dari pengembangan transferable skills mahasiswa ini adalah dapat dikembangkan melalui peningkatan kualitas pembelajaran selama masa studi berlangsung. Konsep ini sampai saat ini terus dikembangkan di kedua universitas tersebut terutama pada University of Westminster namun belum diukur.

Pondasi kompetensi yang baik dibangun dari bahan soft skills yang baik.Soft skills yang dikembangkan seyogyanya dipilih dari aspek-aspek yang transferable sehingga transferable skills yang dimiliki mahasiswa benar-benar dapat dimanfaatkan untuk menyelesaikan pekerjaan di tempat mereka kelak (Siswandari, 2006; Siswandari dan Susilaningsih, 2006; 2007; 2008), misalnya:

(1) Kemampuan berkomunikasi secara efektif didalam tim kerja (ingat bahwa kemampuan berkomunikasi termasuk kedalam soft skill); (2) Kemampuan bernegosiasi dengan winwin solution (harap diingat pula bahwa kemam-puan bernegosiasi saja termasuk kedalam soft skill); (3) Kemampuan menilai manfaat penggunaan IT secara benar; (4) Kemampuan bekerjasama didalam kelompok dengan mematuhi pembagian kerja dan tanggungjawab; (5) Kemampuan menghargai orang lain berdasarkan kompetensi yang dimiliki; (6) Kemampuan memimpin tim secara adil dan demokratis.

Selanjutnya, ciri kepribadian yang dianggap sangat penting untuk dikembangkan (Loogma, 2004; Parry, 1998)) antara lain: (1) Bertanggung jawab; (2) Jujur; (3) Inisiatif; (4) Setia; dan (5) Mandiri

Disamping itu, ciri kepribadian lain yang sebaiknya juga dikembangkan adalah: (1) Percaya diri (karena Allah akan memberikan kekuatan dan petunjuk jika seseorang berniat melakukan kebaikan); (2) Pemurah (tidak pelit) secara material dan non-material misalnya dalam hal membagi pengetahuan dan keterampilan atau menunjukkan nilai-nilai yang menurut pengukuran tertentu dipandang baik; (3) Pekerja keras; (4) Peduli terhadap lingkungan kerja dan social

Demikian pula nilai-nilai unggul yang sebaiknya dikembangkan antara lain: (1) Memiliki etos kerja yang unggul dimana dosen memiliki pandangan bahwa kerja harus dilakukan atas dasar pengetahuan, ketrampilan dan sikap yang benar, malu jika hasil pekerjaanya kurang baik, dan selalu meningkatkan kualitas hasil kerja dari waktu ke waktu; (2) Selalu berusaha untuk do the best; sehingga tidak pernah terlintas sedikitpun dalam benaknya bahwa pekerjaan akan dilakukan sekadarnya tanpa perencanaan dan hasil yang dapat diukur atau diamati; (3) Selalu berorientasi pada action dan ;product; tidak cenderung menghabiskan waktu untuk bicara yang tidak karuan dan tanpa hasil; (4) Meyakini bahwa pekerjaan apapun harus dipertanggungjawabkan tidak hanya kepada atasan di dunia namun terutama harus dipertanggungjawabkan kepada Allah, Tuhan Yang Maha Esa setelah yang bersangukutan meninggal dunia; (5) Tidak mengambil hak orang lain; Selalu berupaya untuk bersikap adil bahkan terhadap musuh; den gan semangat untuk kebaikan penyelenggaraan institusi

Teori pengembangan skills dan transferable skills yang dikemukakan oleh Copland (2006, 2004) maupun Curzon (1985), dimana transferable skills ini dapat dikembangkan melalui peningkatan kualitas pembelajaran. Peningkatan kualitas pembelajaran ini antara lain dapat diterjemahkan oleh peneliti kedalam peningkatan tiga tahap proses pembelajaran yaitu (1) tahap perencanaan 
atau perancangan pembelajaran, (2) tahap pelaksanaan pembe-lajaran dan (3) tahap pengukuran.Dengan demikian berdasarkan hasil penelitian ini dapat dikemukakan bahwa pengembangan transferabkle skills mahasiswa dapat dilakukan melalui peningkatan kualitas pembelajaran secara terpadu (terutama yang berkaitan dengan perumusan tujuan pembelajaran yang didasarkan pada kurikulum dan hasil kajian atau prediksi terhadap permintaan pasar kerja; perancangan strategi pembelajaran yang diharapkan dapat meningkatkan pengetahuan, ketrampilan; terutama transferable skills dan sikap positif mahasiswa untuk terus mengembangkannya dalam rangka menunjang pencapaian kehidupan yang lebih baik, dan implementasi dari langkah strategis yang telah dirancang tersebut). Hal ini antara lain dimaksudkan untuk mewujudkan tanggung jawab lembaga pendidikan tinggi terhadap stakeholders terutama kepada mahasiswa sebagai calon lulusan yang akan segera memasuki dunia kerja agar memiliki transferable skills yang memadai dan memenuhi tuntutan pengguna kerja yang membutuhkan berbagai spesifikasi ketrampilan dari Sumber Daya Manusia yang akan dipekerjakan

\section{Manajemen Sumber Daya Manusia}

Sumber daya manusia merupakan salah satu faktor yang penting dalam suatu organisasi atau perusahaan, disamping faktor lain seperti modal. Oleh karena itu, sumber daya manusia harus dikelola dengan baik untuk meningkatkan efektivitas dan efisiensi organisasi, sebagai salah satu fungsi dalam perusahaan yang dikenal dengan manajemen sumber daya manusia.

Menurut Marihot Tua E.H. dalam Sunyoto (2012:1), manajemen sumber daya manusia didefinisikan: Human resource management is the activities undertaken to attact, develop, motivate, and maintain a high performing workforce within the organization (Manajemen sumber daya manusia adalah aktivitas yang dilakukan merangsang, mengembangkan, memotivasi, dan memelihara kinerja yang tinggi dalam organisasi). Berdasarkan definisi di atas pula, Marihot Tua mengatakan bahwa sumber daya manusia dengan keseluruhan penentuan dan pelaksanaan berbagai akivitas, policy, dan program yang bertujuan untuk mendapatkan tenaga kerja, pengembangan, dan pemeliharaan dalam usaha meningkatkan dukungannya terhadap peningkatan efektivitas organisasi dengan cara yang secara etis dan sosial dapat dipertanggungjawabkan.

Menurut Hasibuan (2007:10), manajemen sumber daya manusia adalah ilmu dan seni mengatur hubungan dan peranan tenaga kerja agar efektif dan efisien membantu terwujudnya tujuan perusahaan, karyawan, dan masyarakat. Fungsi-fungsi MSDM terdiri dari perencanaan, pengorganisasian, pengarahan, pengendalian, pengadaan, pengembangan, kompensasi, pengintegrasian, pemeliharaan, kedisiplinan, dan pemberhentian.

Menurut Kiggundu dalam Cardoso Gomes (2003:4) Manajemen sumber daya manusia dalam perspektif internasional, atau makro adalah: "Human resource management ... is the development and utilization of personnel for the effective achievement of individual, organizational, community, national, and international goals and objectives, (manajemen sumber daya manusia adalah pengembangan dan pemanfaatan personil (pegawai) bagi pencapaian yang efektif mengenai sasaran-sasaran dan tujuantujuan individu, organisasi, masyarakat, nasional, dan internasional). Sedangkan 
pengertian MSDM dalam perspektif mikro, biasanya sama dengan pengertian yang diberikan terhadap manajemen personalia, seperti dijelaskan oleh Flippo dalam Handoko (2011:3), manajemen personalia adalah perencanaan, pengorganisasian, pengarahan, dan pengawasan kegiatan-kegiatan pengadaan, pengembangan, pemberian kompensasi, pengintegrasian, pemeliharaan dan pelepasan sumber daya manusia agar tercapai berbagai tujuan individu, organisasi dan masyarakat.

Definisi yang senada juga dikemukakan oleh French dalam Handoko (2011:3), mendefinisikan manajemen personalia sebagai penarikan, seleksi, pengembangan, penggunaan dan pemeliharaan sumber daya manusia oleh organisasi. Menurut Tulus dalam Cardoso Gomes (2003:6), MSDM adalah perencanaan, pengorganisasian, pengarahan dan pengawasan atas pengadaan, pengembangan, pemberian kompensasi, pengintegrasian, pemeliharaan dan pemutusan hubungan tenaga kerja dengan maksud untuk membantu mencapai tujuan organisasi, individu, dan masyarakat.

Sedangkan menurut Bangun (2012:6), Manajemen Sumber Daya Manusia adalah suatu proses, perencanaan, pengorganisasian, penyusunan staf, penggerakan, dan pengawasan, terhadap pengadaan, pengembangan, pemberian kompensasi, pengintegrasian, pemeliharaan dan pemisahan tenaga kerjauntuk mencapai mencapai tujuan organisasi. Menurut Sofyandi (2008:6), Manajemen Sumber Daya Manusia adalah: "Suatu strategi dalam menerapkan fungsi-fungsi manajemen yaitu planning, organizing, leading, dan controlling, dalam setiap aktivitas/fungsi operasional SDM mulai dari proses penarikan, seleksi, pelatihan dan pengembangan, penempatan yang meliputi promosi, demosi, dan transfer, penilaian kinerja, pemberian kompensasi, hubungan industrial, hingga pemutusan hubungan kerja, yang ditujukan bagi peningkatan kontribusi produktif dari SDM organisasi terhadap pencapaian tujuan organisasi secara lebih efektif dan efisien."

Menurut Cahayani (2009:1) definisi MSDM ada beragam. Hanya sedikit ahli tentang Sumber Daya Manusia (SDM) yang mengutarakan definisi MSDM. Berikut ini dipaparkan sejumlah definisi tersebut: Definisi dari Garry Dessler: ... The policies and practices one needs to carry out the 'people' or human resource aspects of a management position, including recruiting, screening, training, rewarding, and appraising. Definisi dari Beer et al.: Human Resource management involves all management decisions and action that affect the relationship between the organization and employee-its human resources.

Definisi dari Pettigrew dan Whipp: Human resource management relates to the total set of knowledge, skills, and attitudes that firms need to complete. It involves concern for and action in the management of people, including: and compensation. Such action may be bound together by the creation of an HRM philosophy. Definisi dari Michael Amstrong: MSDM dapat didefinisikan sebagai pendekatan stratejik dan koheren untuk mengelola aset paling berharga milik organisasi-orang-orang yang bekerja di dalam organisasi, baik secara individu maupun kolektif, guna memberi sumbangan untuk pencapaian sasaran organisasi. Dari keempat definisi diatas, dapat disimpulkan bahwa MSDM berkaitan dengan pengelolaan manusia yang berada di dalam suatu organisasi yang ingin mencapai tujuan bersama, yaitu tujuan organisasi. Dalam sejumlah definisi di atas juga dapat dilihat bahwa pengelolaan manusia dimulai sejak tahap perekrutan dan seleksi hingga tahap penilaian kinerja dan 
pemberian imbalan.

Menurut Budiyanto (2013:47), Manajemen Sumber Daya Manusia adalah: "Kombinasi kegiatan yang berdampak biaya atas adanya pengelolaan sumber daya manusia, tetapi dampak biaya tersebut tidak seharus dilihat sebagai biaya, Manajemen sumber daya manusia memandang manusia dalam organisasi sebagai aset yang perlu dirawat, ditingkatkan kemampuan keterampilan dan menjaga komitmennya dalam bekerja, hal-hal tersebut akan berdampak pada peningkatan daya saing yang unggul (competitive advantage)." Manajemen Sumber Daya Manusia menurut Ikhsan (2008:3), dapat diartikan sebagai kegiatan perencanaan, pengorganisasian, pengarahan dan pengendalian atas pengadaan tenaga kerja, pengembangan, kompensasi, integrasi, 16 pemeliharaan dan pemutusan hubungan kerja dengan sumber daya manusia untuk mencapai sasaran perorangan, organisasi dan masyarakat. Menurut Stoner dalam Ikhsan (2008:3), Manajemen Sumber Daya Manusia adalah suatu prosedur berkelanjutan yang bertujuan untuk memasok suatu organisasi atau perusahaan atau orang-orang yang tepat untuk ditempatkan pada posisi dan jabatan yang tepat pada saat organisasi memerlukan.

\section{METODE PENELITIAN}

Untuk memperoleh data tentang program pembelajaran mata kuliah praktis diprodi Ikom UTM digunakan teknik pengambilan data melalui observasi dan wawancara dalam yang dilakukan kepada dosen pengampu mata kuliah praktis ilmu komunikasi Wawancara ini dilakukan dengan cara tak terstruktur tapi mendalam dan dalam suasana terbuka. Pedoman wawancara dilakukan sespesifik mungkin agar informasi dapat digali sebanyakbanyaknya tetapi dalam suasana subyek tidak merasa diwawancarai. Wawancara mendalam juga dilakukan kepada jajaran pejabat prodi ikom (Kajur, sekjur, kepala Laboratorium) untuk memperoleh data tentang program pembelajaran praktis yang slam ini telah dilakukan, beserta kendala-kendala yang dihadapinya.

Selain itu wawancara terstruktur, dan observasi juga dilakukan pada mahasiswa ilmu komunikasi mengenai pengetahuan, sikap, prilaku mahasiswa ikom terhadap materi mata kuliah praktis di prodi ikom UTM beserta hambatan hambatan yang terjadi dalam proses pembelajaran.

Teknik pengambilan data juga dilakukan melalui metode FGD. Teknik ini untk menghasilkan rumusan desain tranferable skill yang diterapkan dalam mata kuliah praktis ilmu komunikasi melalui media bengkel kerja komunikasi. Teknik ini dilakukan oleh peneliti bersama-sama dengan dosen dan jajaran pejabat prodi ilmu komunikasi.

\section{PEMBAHASAN}

\section{Pengelolaan Sumber Daya Manusia Untuk Menciptakan Kompetensi}

Pengembangan SDM berbasis kompetensi dilakukan agar dapat memberikan hasil yang sesuai dengan tujuan dan sasaran organisasi dengan standar kinerja yang telah ditetapkan. Kompentensi menyangkut kewenangan setiap individu untuk melakukan tugas atau mengambil keputusan sesuai dengan perannnya dalam organisasi yang relevan dengan keahlian, pengetahuan dan kemampuan yang dimiliki. Kompetensi yang dimiliki karyawan secara individual harus mampu mendukung pelaksanaan strategi organisasi dan mampu mendukung setiap perubahan yang dilakukan manajemen. Dengan kata lain kompentensi yang dimiliki individu 
dapat mendukung system kerja berdasarkan tim. Pengelolaan sumber daya manusia, dalam hal ini mahasiswa komunikasi diharapkan mampu meningkatkankan kompetensi mereka dan mampu bersaing dengan mahasiswa dari berbagai perguruan tinggi komunikasi.

\section{Pengelolaan Keragaman Sumber Daya Manusia Untuk Meraih Keunggulan}

Mengelola diversitas angkatan kerja berarti menarik, mempertahankan, memotivasi individu-individu dengan latar belakang yang beragam dan bervariasi berkaitan yang dengan ras, jenis kelamin, asal-usul, bahasa, status perkawinan, dan pendidikan (Cox dan Blake, 1991). Selama era 1990-an dan memasuki abad 21 diversitas sumber daya manusia menjadi komponen utama fenomena tenaga kerja dalam organisasi. Keragaman merupakan isu strategis saat ini dan pada masa yang akan datang. Perubahan-perubahan demografi dalam menciptakan tantangan baru bagi manajer dalam organisasi.

Perbedaan-perbedaan diantara individu sering menciptakan konflik dalam organisasi. Jika konflik tidak ditangani secara cepat maka akan menghasilkan kinerja yang buruk. Isu-isu diversitas dapat mempengaruhi perilaku SDM di seluruh organisasi, departemen-departemen yang ada, kelompok-kelompok kerja, hubungan-hubungan atau interaksi dua arah (dyadic) dalam organisasi. Organisasi yang sukses adalah organisasi yang menanggapi masalah diversitas secara proaktif. Fenomena diversitas perlu diperhatikan dalam proses perencanaan strategis SDM (Foster, 1988). Para praktisi SDM, ahli pengembangan organisasional, konsultan, dan spesialis SDM diharapkan membantu mengelola pelatihan dan melakukan dinamika pelatihan SDM serta memecahkan masalah-masalah yang berkaitan dengan sumber daya manusia. Dalam pengelolaan Bengkel Kerja Komunikasi sebagai laboratorium diharapkan mampu melatih maasiswa menjadi mahasiswa yang mampu mengelola konflik secara sehat, yang pada akhirnya membantu menciptakan iklim organisasi yang sehat dan efektif.

\section{Pengelolaan Sumber Daya Manusia Untuk Meningkatkan Daya Saing}

Organisasi-organisasi saat ini mengakui bahwa kesuksesan dan daya saing sangat tergantung pada tingkat efisiensi dan keefektifan operasional dan strategik. Tingkat efisiensi dan keefektifan operasional meliputi (Flaherty, 1996):

- Restrukturisasi operasi.

- Penurunan biaya operasi.

- Peningkatan kualitas barang dan jasa.

- Inovasi secara terus menerus.

- Pengembangan produk baru.

Seiring dengan perubahan kondisi lokal, nasional maupun global, disertai persaingan seru, maka dunia kerja dan organisasinya mengalami perubahan juga. Masalah-maslah yang berkaitan dengan sumber daya manusia terus berkembang dan menyebar pada seluruh organisasi yang ada saat ini. Segala upaya yang diperlukan untuk menciptakan suatu organisasi yang berhasil tergantung pada perubahan yang signifikan dalam MSDM. Berbagai upaya yang dilakukan organisasi adalah:

- Perampingan organisasi (downsizing) yang meliputi pensiun, pemberian uang pesangon, suksesi manajemen dan program-program perencanaan SDM yang lebih baik untuk mengurangi terjadinya downsizing lebih lanjut.

- Desentralisasi melibatkan upaya melatih pekerja dalam pembuatan keputusan, 
penilaian kerja, perubahan-perubahan kompensasi, dan ketrampilan ketrampilan kepemimpinan (leadership) yang baru.

Berdasarkan pengalaman-pengalaman eksekutif tidak ada organisasi yang fleksible, yang ada hanya orang-orang yang fleksible.

\section{BKK sebagai bentuk pemberdayaan ma- hasiswa sebagai sumber daya manusia (SDM)}

Bengkel Kerja Komunikasi (BKK) sebagai laboratorium adalah bagian integral dari bidang akademik, sehingga dalam manajemen laboratorium perlu direncanakan secara tepat. Peranan laboratorium sangat besar dalam menentukan mutu pendidikan karena laboratoriumlah yang menghasilkan karyakarya yang membanggakan, yang tak dapat dihasilkan oleh institusi lainnya. Sehingga bagi perguruan tinngi yang bermutu, laboratorium menjadi bagian yang dikedepankan.

Manual Prosedur Pengelolaan Laboratorium adalah serangkaian tindakan yang harus dilakukan oleh pengelola laboratorium agar penjaminan mutu laboratorium bisa dilaksanakan dengan baik. Tindakan-tindakan tersebut meliputi perencanaan, pelaksanaan, pengendalian, dan penyempurnaan laboratorium.

Prosedur pengelolaan BKK sebagai laboratorium adalah langkah-langkah yang harus dilakukan oleh pengelola agar laboratorium yang dikelolanya bermutu.

Dalam pengelolaan laboratorium, pengelolaannya meliputi beberapa aspek yaitu: 1) perencanaan, 2) penataan, 3) pengadministrasian, 4) pengamanan, perawatan, pengawasan

\section{Perencanaan}

Perencanaan merupakan sebuah proses pemikiran yang sistematis, analitis, logis tentang kegiatan yang harus dilakukan, langkah-langkah, metode, SDM, tenaga dan dana yang dibutuhkan untuk mencapai tujuan yang telah ditentukan secara efektif dan efisien.

Perencanaan ini dimaksudkan untuk merencakan konsep dari suatu laboratorium itu sendiri. Bagaimanakah bentuk laboratorum yang ideal? Berapa besarkah ukurannya? Pertanyaan-pertanyaan ini tidak serta merta dapat kita dijawab, karena sebuah laboratium dibangun untuk tujuan tertentu. Artinya sebelum laboratorium itu dibangun harus tahu dulu untuk keperluan apa dan untuk dipakai siapa laboratorium tersebut. Pada umumnya bentuk, ukuran dan tata ruang suatu laboratorium didesain sedemikian rupa sehingga pemakai laboratorium mudah melakukan aktivitasnya.

\section{Penataan}

Tata letak peralatan adalah suatu bentuk usaha pengaturan penempatan peralatan di laboratorium, sehingga laboratorium tersebut berwujud dan memenuhi persyaratan untuk beroperasi. Kata pengaturan dalam kalimat di atas mengandung makna yang sangat luas, yaitu bahwa dalam mewujudkan suatu laboratoriumyang layakoperasi diperlukan penempatan perlatan yang tersusun yang rapi berdasar kepada proses dan langkahlangkah penggunaan/aktivitas dalam laboratorium yang diharapkan, begitu pula dengan daerah kerja harus memiliki luas yang memungkinkan pengguna/pekerja/ operator dapat bergerak bebas, aman dan nyaman, di samping lalu lintas bahan yang akan digunakan dapat sampai ke tempat kerja dengan mudah dan lancar. 


\section{Tujuan Tata Letak Laboratorium}

1. Mengurangi hambatan dalam upaya melaksanakan suatu pekerjaan yang menjadi tanggung jawabnya.

2. Memberikan keamanan dan kenyamanan bagi pengguna/pekerja/operato.

3. Memaksimalkan penggunaan peralatan.

4. Memberikan hasil yang maksimal dengan pendanaan yang minimal

5. Mempermudah pengawasan.

Prinsip-prinsip yang perlu diperhatikan dalam menyusun tata letak peralatan dan perabotan laboratorium adalah:
a. Mudah dilihat
b. Mudah dijangkau
c. Aman untuk alat
d. Aman untuk pemakai

\section{Pengadministrasian}

Pengadministrasian sering juga disebut sebagai kegiatan menginventaris. Inventaris adalah sutu kegiatan dan usaha untuk mnyediakan catatan tentang keadaan semua fasilitas, barang-barang yang dimiliki sekolah. Bagi laboratorium ilmu komunikasi yang memiliki beberapa jenis laboratorium, sangat penting untuk mendata fasilitas/menginventaris alat dan bahan laboratorium untuk kegiatan pembelajaranmahasiswa. Dengankegiatan invetarisasi yang memadai akan dapat diperoleh pedoman untuk mempersiapan anggaran atau mempersiapkan kegiatan pada tahun yang akan datang.

Catatan inventaris yang baik akan mempermudah pergantian tanggung jawab dari pengelola yang satu ke yang lainnya. Inventaris juga akan mempermudah untuk mengetahui dimana suatu peralatan akan ditempatkan. Dengan demikian akan mempermudahkan pengontrolan, seperti terhadap kehilangan yang disebabkan oleh kecerobohan atau tindak pencurian.

Dalam pengeloaan laboratorium, ada beberapa daftar alat inventarisasi yang harus digunakan atau diisi, diantaranya:

1. Buku Induk Barang Inventaris

2. Buku Catatan Barang Inventaris

3. Buku Golongan Barang Inventaris

4. Laporan Triwulan Mutasi barang

5. Daftar Isian Barang

6. Daftar Rekapitulasi barang Inventaris Contoh format dokumen/ alat inventaris yang telah banyak dikembangkan dan digunakan:

\begin{tabular}{|l|c|c|c|c|}
\hline \multirow{2}{*}{ No } & \multirow{2}{*}{$\begin{array}{c}\text { Nama } \\
\text { barang } \\
\text { Inventaris }\end{array}$} & $\begin{array}{c}\text { Daftar Isian barang Inventaris yang } \\
\text { Inelompok } \\
\text { Barang }\end{array}$ & $\begin{array}{c}\text { Kode } \\
\text { Barang }\end{array}$ & $\begin{array}{c}\text { Jumlah } \\
\text { barang }\end{array}$ \\
\hline 1. & & & & \\
\hline 2. & & & & \\
\hline
\end{tabular}

\section{Pengamanan, perawatan, dan pengawasan}

Pada dasarnya pengamanan, perawatan dan pengawasan laboratorium merupakan tanggung jawab bersama baik pengelola maupun pengguna. Mengatur dan memelihara laboratorium merupakan upaya agar laboratorium selalu tetap berfungsi sebagaimana mestinya. Sedangkan upaya menjaga keselamatan kerja mencakup usaha untuk selalu mencegah kemungkinan terjadinya kecelakaan sewaktu bekerja di laboratorium dan penangannya bila terjadi kecelakaan

Dalam manajemen laboratorium, harus didesain untuk memperbaiki efektifitas serta efisiensi kerjanya, disamping harus mempertimbangkan kebutuhan semua pihak yang berkepentingan dalam laboratorium. 
Beberapa hal yang harus kita perhatikan dalam manajemennya adalah sumber daya manusia, saran dan prasarana dan juga penggunaan labolatorium.

Dalam pengunaan laboratorium baik digunakan untuk praktikum ataupun penelitian harus menyerahkan jadwal pennggunaanya terlebih dahulu, hal ini dimaksudkan agar tidak terjadi tumpang tindih dalam penggunaan laboratorium. Selain itu kita juga harus menggunakan peralatan laboratorium saat menggunakan laboratorium, dan juga mengikuti semua prosedur peminjaman alat serta permintaan bahan yang berlaku.

Secara umum laboratorium mempunyai fungsi diantaranya :

\section{Tempat dilakukannya produksi}

Alat-alat laboratorium serta bahan-bahan praktikum tidaklah mungkin diletakkan dalam kelas maka dari itu percobaan dilakukan di dalam laboratoriu.

\section{Tempat penunjang kegiatan kelas.}

Dengan adanya kegiatan pembelajaran di laboratorium ini, mahasiswa dapat mengamati dan mempraktekkan secara langsung, bukan hanya belajar menurut teori saja

\section{Sebagai tempat display atau pameran.}

Laboratorium juga bisa dipergunakan sebagai tempat pameran atau display dari hasil-hasil karya mahasiswa atau produksi yang telah kita lakukan. Sehingga dapat memotivasi untuk menghasilkan karya yang lebih baik lagi.

\section{Tempat koleksi karya dosen maupun} mahasiswa.

Hasil dari praktikum sejumlah matakuliah dapat kita kumpulkan serta diklasifikasikan, sehingga laboratorium dapat kita gunakan sebagai museum atau galeri mini.

Dalam pembelajaran di laboratorium mempunyai tujuan tertentu bagi mahasiswa komunikasi, diantaranya:

a. Teliti dalam melakukan produksi suatu program acara maupun kegiatan tertentu

b. Dapat menafsirkan dan menganalisa hasil produksi serta memecahkan masalah yang muncul dari proses tersebut

c. Mampu untuk membuat rencana dan melaksanakan kegiatan suatu produksi

d. Terampil dalam menggunakan alatalat laboratorium.

e. Tumbuh sikap positif terhadap kegiatan praktikum.

\section{DAFTAR PUSTAKA}

Atik, Purmiyati.2004.Studi tentang Faktor-Fakyor yang Mempengaruhi Minat Mahasiswa untuk Berwirausaha.Laporan Penelitian,Universitas Airlangga : Surabaya.

Bangun, Wilson, 2012, Manajemen Sumber Daya Manusia, Erlangga, Bandung

Budiyanto, Eko, 2013. Manajemen Sumber Daya Manusia, Graha Ilmu, Jakarta.

Cahayani, Ati. 2010. Strategi dan Kebijakan Manajemen Sumber Daya Manusia. Jakarta: PT Indeks 
Cendrasari,Nur Kartika,2000.Analisis Pengangguran di Indonesia Berdasarkan Data Sakerti 1993. Tesis, Universitas Indonesia : Jakarta.

Cox, T.H., dan S. Blake. 1991. "Managing Cultural Diversity: Implications for Organizational Competitiveness". Academy of Management Executive. 5: 45-56.

Foster, R.P. 1988. "Work Force Diversity and Business". Training and Development Journal. April: 39.

Gomes, Faustino Cardoso, 2003, Manajemen Sumber Daya Manusia, Penerbit Andi, Yogyakarta.

Gumgum Gemelar Fajar,Rakhman.2005.Sumbangan Harga Diri dan Locus dengan Coping Stress pada Pengangguran Laki-Laki dan Perempuan Lulusan Sekolah Menengah Kejuruan. Tesis, Universitas Indonesia: Jakarta

Handoko, T Hani, 2000, Manajemen Sumber Daya Manusia, BPFE, Yogyakarta

Hasibuan, Malayu SP, 2000, Manajemen Sumber Daya Manusia, Penerbit Bumi Aksara, Jakarta.

Ikhsan, Arfan, 2008. Akuntansi sumber Daya Manusia:Suatu Tinjauan Penilaian Modal Manusia, Graha Ilmu, Yogyakarta

Iskandar, Triyana.Pengaruh Upah Minimum terhadap Tingkat Pengangguran di Indonesia Periode 1988-1993.Tesis, Universitas Indonesia : Jakarta

Koentjaraningrat, 1986.Metode-Metode Penelitian Masyarakat.Jakarta : Gramedia

Patton, M.Q .1980.Qualitative Evaluation Methods.Beverly Hills, CA: Sage Publication.

Setyadi,dody.1997. Analisis Pengangguran Tenaga Kerja Terdidik dengan Pendekatan Search Theory pada Pasar Kerja di Jawa Tengah. Tesis, Universitas Indonesia: Jakarta

Siagian, Sondang P, 2007, Manajemen Sumber Daya Manusia, Edisi Pertama, Cetakan Keempatbelas, Penerbit Bumi Aksara, Jakarta.

Siswandari, 2009. Peningkatan Kualitas Pembelajaran Statistika dalam rangka Mengembangkan Transferable Skills Mahasiswa. Jurnal Pemikiran dan Penelitian Pendidikan Tinggi Akademika Volume 1 No. 1 Januari 2009.

Sofyandi, Herman 2008, Manajemen Sumber Daya Manusia, Edisi Pertama,. Penerbit Graha Ilmu, Yogyakarta.

Sunyoto, D. 2012. Manajemen Sumber Daya Manusia. Yogyakarta : CAPS

Sutopo, H. B. 2002. Metodologi Penelitian Kualitatif. Surakarta: Sebelas Maret University Press, 2002. 
Wirasasmita,Yuyun.2010.Peran Alumni dan Perguruan Tinggi dalam Mengembangkan Jiwa Kewirausahaan di Semua Sektor Menuju 'Entrepreneurial Economy'.Akses 10 April 2011.http://www.universitasborobudur.ac.id

Wiyono,Sutarto dkk.2009.Model Pelatihan Memasuki Dunia Kerja Berbasis Link and Match. Laporan Penelitian.Universitas Kristen Satya Wacana : Salatiga.

\section{Sumber lain :}

Butuh Kewirausahaan, akses tanggal 14 April 2011, http://dikti.kemdiknas.go.id

The Entrepreneurial Campus Initiative:Understanding the Entrepreneurial Orientation of Srudents.2005.Research Report.Nortland Foundation and Northeast Entrepreneur Fund : Center for Rural Policy and Development.

Wirus entrepreneurship, akses tanggal 14 April 2011, http://dikti.kemdiknas.go.id

Moh Amin. 1988. Konsorsium Ilmu Pendidikan, diakses 28 Maret 2011 dari http://sulistyok. blogspot.com/2010/12/pengeloaandan penataan laboratorium.html 